\title{
The UN 1994 Human Development Report Presents Concrete Proposals for the Social Summit
}

\author{
Human Security is the Central Theme: \\ Canada is Ranked First in Overall Human Development
}

"The world can never be at peace unless people have security in their daily lives," warns the Human Development Report 1994. The annual report, published for the United Nations Development Programme (UNDP), is prepared by a team of world-renowned independent scholars under the guidance of Mahbub ul Haq, former Finance Minister of Pakistan and currently Special Adviser to the UNDP Administrator. The Human Development Report 1994 advances a new concept of human security and offers several concrete proposals for the World Summit for Social Development in March 1995 in Copenhagen.

"The Summit will be a time to respond to the new compulsions of human security," says James Gustave Speth, Administrator of UNDP, in a foreword to the report. "It will be a time to reiterate very clearly that, without the promotion of people-centred development, none of our key objectives can be met-not peace, not human rights, not environmental protection, not reduced population growth, not social integration. It will be a time for all nations to recognize that it is far cheaper and far more humane to act early and to act upstream than to pick up the pieces downstream, to address the root causes of human insecurity rather than their tragic consequences."

The 1994 report, which is published for UNDP in English by Oxford University Press and in French, Spanish, Arabic, Danish, German, Italian and

This summary is based on the press release from the United Nations Development Programme (UNDP).

The Human Development Report 1994 is published in English by Oxford University Press, 2001 Evans Road, Cary, NC 27513, USA. Telephone: (919) 677-0977; Toll free in the USA: (800) 451-7556; Fax: (919) 6771303. Price: US\$17.95.
Portuguese by publishers of those languages, is in its fifth year as a major source of new development thinking and advocacy for change. As in the past years, its core is the Human Development Index (HDI), which ranks 173 countries by a measure that combines life expectancy, educational attainment and basic purchasing power.

This year Canada ranked first in human development overall, while Barbados ranked first among developing countries. A new measurement showing HDI progress over the years 1960-1992 reveals that among 114 countries for which data was available, Malaysia and Botswana showed most progress, with the Republic of Korea, Tunisia and Thailand closely following. The region showing the most human development progress, East Asia, also showed the fastest economic growth. "This shows that the fast pace of economic growth in East Asia was built on a solid foundation of human development," says the report.

The thrust of this year's report, however, is in the foundation it lays for the Social Summit. The report recommends that the Summit endorse the emerging concept of human security as the basis upon which national development strategies, international cooperation and global governance should be organized.

The report points out that human security is relevant to people everywhere, in rich nations and in poor. Its reach is now global. "Famines, ethnic conflicts, social disintegration, terrorism, pollution and drug trafficking are no longer isolated events, confined within national borders. Their consequences travel the globe," warns the report. Adds Mahbub ul Haq: "Just imagine for a moment that every drug that quietly kills, every disease that silently travels, every form of pollution that roams the globe, every act of ter- rorism that destroys life senselesslyjust imagine for a moment that they all carried a national label of origin, much as traded goods do. We would realize with a sudden shock that concerns for human security are more globalized today than even global trade."

The report offers an early warning system to anticipate national breakdowns resulting from persistent threats to human security. It identifies several countries already in deep crisis, such as Afghanistan, Angola, Haiti, Iraq, Mozambique, Myanmar (Burma), Sudan and Zaire. The seeds of their crises lie chiefly in the socioeconomic deprivation of their peoples and political repression by their governments. Acquisition of more arms only aggravates their existing human deprivation.

It also graphically illustrates the recent acquisition of arms by several countries-China, India, Iran, the Republic of Korea, Malaysia, Nigeria, Pakistan-and how much it really cost them in terms of their unmet social agendas.

The report points out that global military spending has been declining since 1987 at the rate of 3.6 per cent a year, and has resulted in a cumulative "peace dividend" of US\$935 billion during 1987-94. But this peace dividend has not been harnessed for unmet human needs. This opportunity should not be lost in future years, says the report.

Other highlights of the report:

- At the beginning of this century, about 90 per cent of war casualties were military. Today, about 90 per cent are civilian-a disastrous shift in the balance.

- Of the 82 conflicts in the last three years, 79 were within nations.

- Many nations have sacrificed human security in the search for more sophisticated arms. For example, India ordered 20 advanced MIG-29 
fighter planes at a cost that could have provided basic education to all the $\mathbf{1 5}$ million girls now out of school. Nigeria bought 80 battle tanks from the United Kingdom at a cost that could have immunized all two million unimmunized children in that country while also providing family planning services to nearly 17 million couples.

- The report calls for the phasing out of all military assistance, military bases and subsidies to arms exporters over a three-year period.

- It recommends a major restructuring of existing aid funds: currently, the poorest 40 per cent of the world's population gets only half as much per capita as the richest 40 per cent; and high military spenders receive two and a half times as much per capita as low military spenders.

- The report proposes a serious study of new institutions for global governance in the 21st century-including a World Central Bank, an International Investment Trust and a World Anti-Monopoly Authority.

The report proposes a concrete agenda for the Social Summit. Included in this agenda are the following:

- A World Social Charter, to arrive at a new social contract among all nations and all people.

- A new development paradigm of sustainable human development: economic growth centred around people that is sustainable from one generation to the next.

- A reduction of 3 per cent a year in future global military spending, with 20 per cent of the savings by rich nations and 10 per cent of poor nations earmarked for global human security.

- A 20:20 global compact for human development-to provide basic education, primary health care, safe drinking water and essential family planning services to all people--by earmarking at least 20 per cent of the existing developing country budgets and 20 per cent of donor aid allocations to these basic human priority concerns.
- A global human security fundfinanced from global taxes such as the Tobin $\operatorname{tax}^{1}$ on speculative movements of international funds, an international tax on consumption of non-renewable energy, global environmental permits and $a$ tax on arms trade.

- A new framework of development cooperation, to graduate from the present aid relationship to a development partnership, by including trade, technology, investment and labour flows in a broader design to be negotiated among nations.

- An Economic Security Council in the United Nations, as the highest decision-making forum to consider basic issues of human security such as global poverty, unemployment, food security, drug trafficking, global pollution, international migration and a new framework for sustainable human development.

The Human Development Report 1994 concludes by observing that "These proposals may at first sight seem to demand a great deal from the international community. But they are probably more realistic than they appear." Mahbub ul Haq reminds the world that "many heresies of yesterday have become the conventional wisdom of today."

\section{Notes}

1. A proposal from Professor James Tobin, winner of the 1981 Nobel Prize for Economics, for the Human Development Report 1994. In 1978 he proposed-after having convinced that speculative currency transactions contribute little to rational long-term investments allocations-an international uniform tax on spot transactions in foreign exchange (a) to increase the weight that market participants give to long-range fundamentals relative to immediate speculative opportunities and (b) to allow greater autonomy to national monetary policy, by making possible larger wedges between short-term interest rates in different currencies. He had estimated that a $0.5 \%$ tax on foreign exchange transactions is equivalent to a $4 \%$ difference in annual interest rates on three-month bills, a considerable deterrent to persons contemplating a quick round trip to another currency. [Ed.]

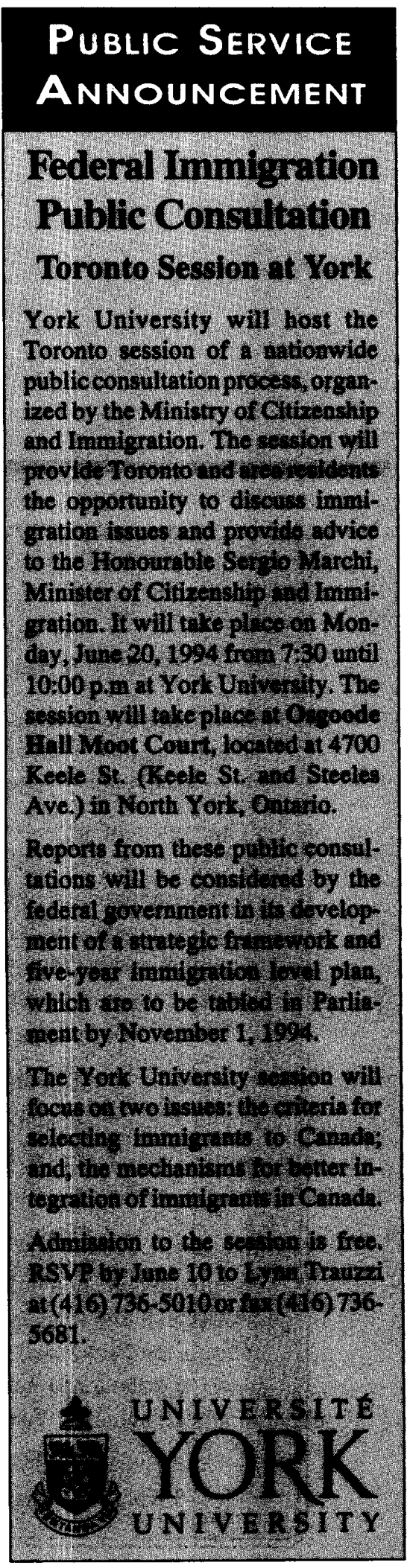

York University wil host the Toronto ression of a Hationich public consuttation preces orgen

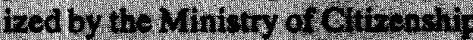
and Inmlgation. Whe sestoifyl

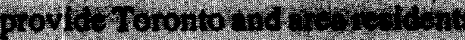

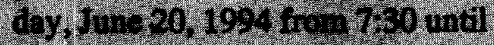

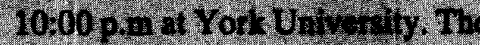

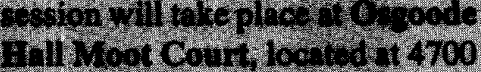

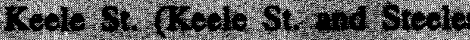

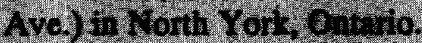

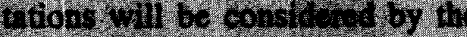

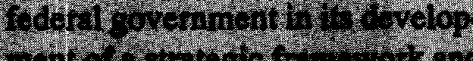
and

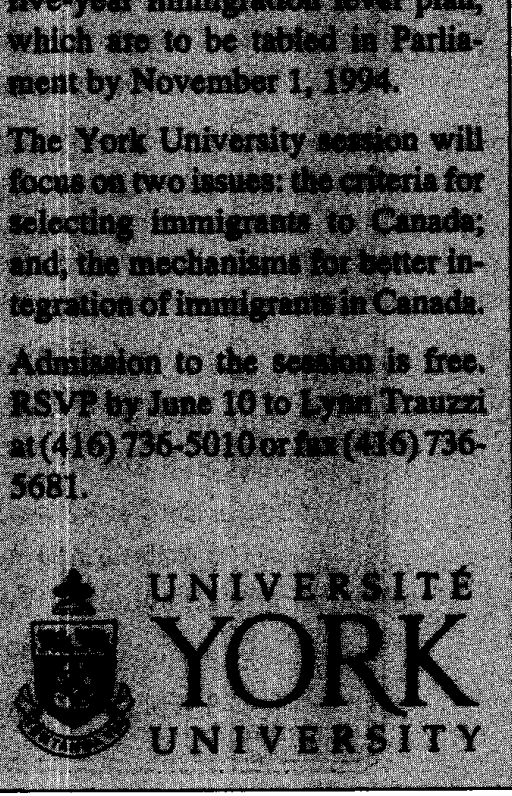

Refuge, Vol. 14, No. 2 (May 1994) 
Centre for Refugee Studies Sulte 351, York Lanes, York University $\mathbf{4 7 0 0}$ Keele Street, North York Ontario, Canada M3J 1 P3

Phone: (416) 736-5843 + Fax: (416) 736-5837

Electronic Mail via Bitnet Address: refuge vm1.yorku.ca

Postage Paid in Toronto, Canada

Second Class Mail Registration No. 5512 Return Postage Guaranteed

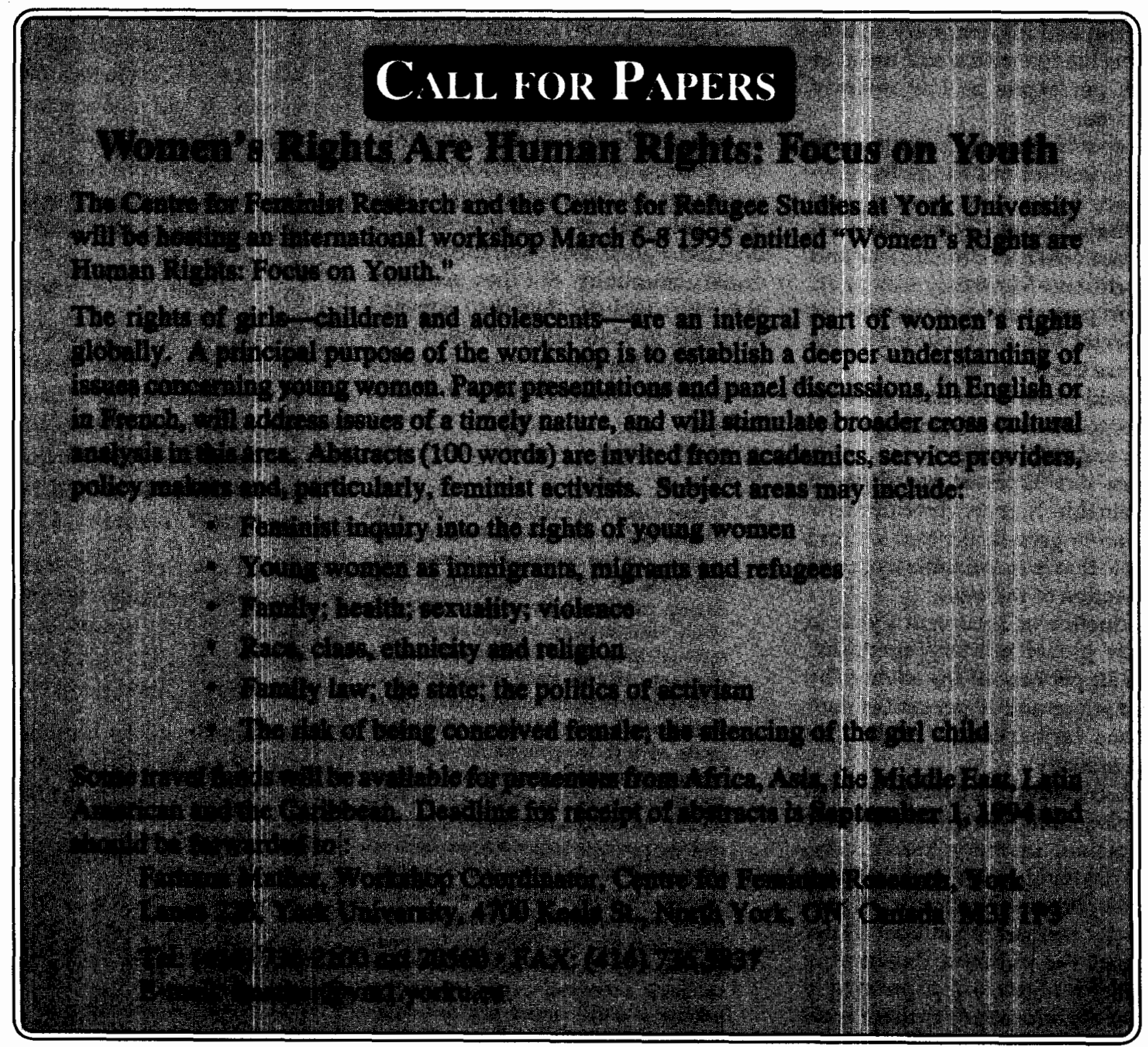

(C) I. Orlova, Y. Streltsova, E. Skvortsova, 1994. This open-access work is licensed under a Creative Commons Attribution-NonCommercial 4.0 International License, which permits use, reproduction and distribution in any medium for non-commercial purposes, provided the original author(s) are credited and the original publication in Refuge: Canada's Journal on Refugees is cited. 